WAR AND RELIGION 



\section{WAR AND RELIGION}

EUROPE AND THE MEDITERRANEAN FROM

THE FIRST THROUGH THE TWENTY-FIRST

CENTURIES

Arnaud Blin

曰 UNIVERSITY OF CALIFORNIA PRESS 
University of California Press, one of the most distinguished university presses in the United States, enriches lives around the world by advancing scholarship in the humanities, social sciences, and natural sciences. Its activities are supported by the UC Press Foundation and by philanthropic contributions from individuals and institutions. For more information, visit www.ucpress.edu.

University of California Press

Oakland, California

(C) 2019 by The Regents of the University of California

Library of Congress Cataloging-in-Publication Data

Names: Blin, Arnaud, author.

Title: War and religion : Europe and the Mediterranean from the first through the twenty-first centuries / Arnaud Blin.

Description: Oakland, California : University of California

Press, [2018] | Includes bibliographical references and index.

Identifiers: LCCN 20I8033I89 (print) | LCCN 2018034560 (ebook) | ISBN 9780520961753 | ISBN 9780520286634 (cloth : alk. paper)

Subjects: LCSH: War-Religious aspects-History. | Religion and politics-Europe-History. | Religion and politicsMediterranean Region-History. | Mediterranean

Region-History. | Europe-History. | Mediterranean

Region-Politics and government. | Europe-Politics and government.

Classification: LCC BL65.W2 (ebook) | LCC BL65.W2 B55 2018 (print) | DDC 20I/.727309-dc23

$\mathrm{LC}$ record available at https://lccn.loc.gov/2018033189

Manufactured in the United States of America

$\begin{array}{llllllll}26 & 25 & 24 & 23 & 22 & 21 & 20 & 19\end{array}$

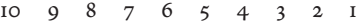


To Kimberly, Margaux, and Emerson 



\section{For six thousand years war}

Has pleased the quarrelling peoples

And God has wasted his time making

The stars and the flowers

-Victor Hugo, Les chansons des rues et des bois 
